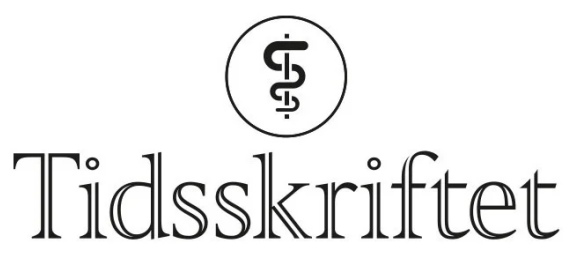

DEN NORSKE LEGEFORENING

\title{
En legeforening for alle leger
}

\author{
KOMMENTAR
}

\section{MARIT HERMANSEN}

Marit.Hermansen@legeforeningen.no

Marit Hermansen er president i Den norske legeforening.

Forfatteren har ikke oppgitt noen interessekonflikter.

Legeforeningen er til for alle leger - og jobber for alle legers interesser. Den offentlige helsetjenesten er grunnfjellet i vårt velferdssystem, og private helsetjenester er et viktig supplement.

En av velferdsstatens viktigste bærebjelker er den offentlige helsetjenesten. Et tilbud som sørger for helsehjelp og trygghet for hele befolkningen, uavhengig av hvem du er eller hvor du bor. Historisk sett har den norske helsetjenesten vært en blandingsmodell, der det private - $i$ all hovedsak ideelle organisasjoner - og offentlige i felleskap har samarbeidet om å skape gode behandlingstilbud.

Det er viktig for pasientene at dette samarbeidet fortsetter. Likevel er det et behov for å bedre kommunikasjonen og samarbeidet mellom den offentlige og private delen av helsetjenesten, til det beste for pasientene og behandlingstilbudet.

Samtidig er Legeforeningen opptatt av å hindre en økt todeling av helsetjenesten. For å unngå det må politikerne prioritere den offentlige helsetjenesten - og det må synes på budsjettene. Hvis våre folkevalgte ikke tar dette ansvaret, kan konsekvensene bli at den offentlige helsetjenesten må bygge ned tilbud, noe som på sikt kan føre til økte forskjeller i samfunnet.

Etter innføringen av Fritt behandlingsvalg, er det flere kommersielle selskaper som får st $\varnothing$ tte fra det offentlige, uten at den offentlige helsetjenesten involveres i vurdering av behov og kvalitet. Vi mener at private og offentlige helseleverandører må være underlagt like strenge krav til kvalitetskontroll.

Det er gledelig at du, Thorleif Jansen, trekker frem «Gjør kloke valg»-kampanjen som et eksempel på initiativ hvor det offentlige og det private kan forene krefter. Gjennom «Gjør kloke valg» arbeider Legeforeningen for å redusere overbehandling og overdiagnostisering. Vi støtter en utredning av omfanget av overbehandling, men det er viktig at en slik utredning ser på hele helsetjenesten.

Norsk helsetjeneste er best tjent med et godt samarbeid mellom det private og det offentlige. Det vil sikre befolkningen et godt helsetilbud. 
(C) Tidsskrift for Den norske legeforening 2023. Lastet ned fra tidsskriftet.no 26. april 2023. 